\title{
Deteksi Dini Masalah dalam Proses Belajar Mengajar Secara Daring Menggunakan Sistem AT-OLP
}

\author{
Karfindo $^{1}$, Rifa Turaina ${ }^{2}$ \\ ${ }^{12}$ STMIK Indonesia Padang \\ ${ }^{1}$ karfindo@ stmikindonesia.ac.id, ${ }^{2}$ rifaturaina@ stmikindonesia.ac.id
}

\begin{abstract}
ABSTRAK. Masa pandemi covid-19 memaksa banyaknya sektor di berbagai bidang untuk melakukan pekerjaan dari rumah, begitu juga dalam bidang pendidikan. Berbagai sekolah mulai dari tingkat dasar sampai tingkat perguruan tinggi, diminta untuk melaksanakan proses belajar mengajar dari rumah secara online atau yang biasa disebut dengan pembelajaran daring. Pemanfaatan e-learning memang membantu dalam pelaksanaan pembelajaran daring, sehingga membuat mahasiswa belajar mandiri dan motivasi meningkat namun ada kesulitan yang terjadi dalam mengontrol pelaksanaan pembelajaran daring sehingga mahasiswa tidak terawasi dengan efektif. Metode penelitian yang digunakan dalam penelitian ini adalah metode FAST karena kerangka kerjanya yang cukup fleksibel untuk berbagai jenis proyek dan strategi. Untuk melakukan control maka digunakan sistem AT-OTP adalah sistem yang digunakan untuk melakukan monitoring terhadap kegiatan proses belajar mengajar secara daring, dengan menggunakan konsep keterbukaan terhadap semua aktifitas yang dilakukan. Sehingga dengan adanya saling terbuka maka masalah yang dihadapi bisa segara diketahui dan dicarikan solusi terhadap permasalah tersebut.
\end{abstract}

Kata Kunci : Pembelajaran daring, e-learning, system AT-OTP

ABSTRACT. The pandemic period covid-19 pandemic period forced many sectors in various fields to do work from home, as well as in education. Various schools ranging from elementary to tertiary level, are asked to carry out the teaching and learning process from home online or what is commonly referred to as online learning. The use of e-learning does help in the implementation of online learning, thus making students learn independently and motivation increases but there are difficulties that occur in controlling the implementation of online learning so that students are not supervised effectively. The research method used in this study is the FAST method because the framework is flexible enough for various types of projects and strategies. To control, the AT-OTP system is used is a system used to monitor the teaching and learning process activities online, using the concept of openness to all activities carried out. So that with the open mutual, the problems faced can be immediately known and sought solutions to these problems.

Keywords: Online learning, e-learning, AT-OTP system

\section{PENDAHULUAN}

Masa pandemi covid-19 memaksa banyaknya sektor di berbagai bidang untuk melakukan pekerjaan dari rumah, begitu juga dalam bidang pendidikan. Berbagai sekolah mulai dari tingkat dasar sampai tingkat perguruan tinggi, diminta untuk melaksanakan proses belajar mengajar dari rumah secara online atau yang biasa disebut dengan pembelajaran daring. Terjadinya peralihan proses belajar mengajar secara mendadak menyebabkan terjadinya kesulitan dan kecemasan baik yang dialami oleh siswa, mahasiswa, guru, dan dosen. Pemicu kecemasan siswa dan mahasiswa selama pembelajaran daring antara lain kesulitan memahami materi, kesulitan mengerjakan tugas-tugas, ketersediaan dan kondisi jaringan internet, kendala teknis, dan kekhawatiran akan tugas selanjutnya. Ditambah lagi dengan keterbatasan aktivitas dan kebosanan selama stay at home yang menimbulkan stress bagi siswa dan mahasiswa selama masa pandemi(Oktawirawan, 2020)(Subang, 2020)(Pakpahan \& Fitriani, 2020).

Memanfaatkan teknologi informasi dalam mendukung proses belajar mengajar secara online, merupakan suatu hal yang harus dilakukan. Karena dengan menggunakan teknologi maka proses belajar mengajar dari rumah dapat terlaksana. Berbagai macam aplikasi bisa digunakan dan diterapkan untuk melaksanakan perkuliahan daring. Aplikasi yang ada dapat membantu dosen dalam memberikan bahan ajar kepada mahasiswa, mahasiswa dan dosen bisa melakukan diskusi terhadap materi yang diberikan, dosen bisa 
memberikan tugas dan dapat mengumpulkan tugas dari mahasiswa. Berbagai macam fitur dari aplikasi elearning yang sangat membantu dalam proses perkuliah daring (Mariko, 2020)(Pujilestari, 2020).

Pemanfaatan e-learning memang membantu dalam pelaksanaan pembelajaran daring, sehingga membuat mahasiswa belajar mandiri dan motivasi meningkat namun ada kesulitan yang terjadi dalam mengontrol pelaksanaan pembelajaran daring sehingga mahasiswa tidak terawasi dengan efektif (Utami, Alan, Cahyono, 2020)(Sadikin et al., 2020)(Setiaji, Ariadi, \& Dinata, 2020) Baik itu perkuliahan yang dilakukan secara synchronous maupun secara asynchronous (Didin, mardiono, \& Yanuarso, 2020).

Dalam kondisi normal setiap mahasiswa akan mengambil setidaknya lebih dari 1 matakuliah dalam satu semester. Itu berarti bahwa bisa dilakukan perbandingan keaktifan mahasiswa pada matakuliah yang diambilnya. Sulit mengetahui mahasiswa sudah mengakses materi yang diberikan oleh dosen dan sulit mengetahui persentasi mahasiswa tersebut mengakses materi dari dosen lainnya. Penggunaan e-learning memang membantu dosen dalam membagikan materi atau bahan ajar kepada mahasiswa, terkadang bahan ajar yang dibagikan oleh dosen tidak di akses oleh mahasiswa. Dosen juga tidak mengetahui apakah mahasiswa yang diajarnya juga tidak mengakses bahan ajar dari dosen yang lainnya. Hal ini diperlukan untuk mengetahui keaktifan mahasiswa dalam mengakses bahan ajar.

Dalam pelaksanaan perkuliahan daring tugas yang diberikan oleh dosen kepada mahasiswa juga sulit untuk dilakukan pengontrolannya. Apakah tugas tersebut sudah dikerjakan oleh mahasiswa atau apakah mahasiswa tersebut ada juga mengerjakan tugasnya pada matakuliah yang lainnya. Dosen tidak bisa mengetahui pengerjaan tugas yang dilakukan oleh mahasiswa pada matakuliah yang lainnya.

Selama perkuliahan daring keaktifan dosen dan mahasiswa juga dapat dilihat dari keikutsertaan mahasiswa dalam berdiskusi. Mahasiswa yang sering terlibat diskusi pada setiap pertemuan bisa dikatakan bahwa mahasiswa tersebut dapat mengikuti perkuliahan. Namun terkadang ada juga mahasiswa yang jarang terlibat diskusi bahkan ada yang tidak terlibat dalam diskusi. Hal ini menimbulkan masalah apakah mahasiswa memang tidak mengerti dengan materi yang diberikan atau ada kendala lainnya. Dosen tidak bisa melihat keterlibatan diskusi mahasiswa dengan matakuliah yang lainnya, apakah dengan matakuliah yang lain mahasiswa tersebut juga tidak ikut terlibat dalam diskusi.

\section{METODE}

Metode penelitian yang digunakan dalam penelitian ini adalah metode FAST karena kerangka kerjanya yang cukup fleksibel untuk berbagai jenis proyek dan strategi.

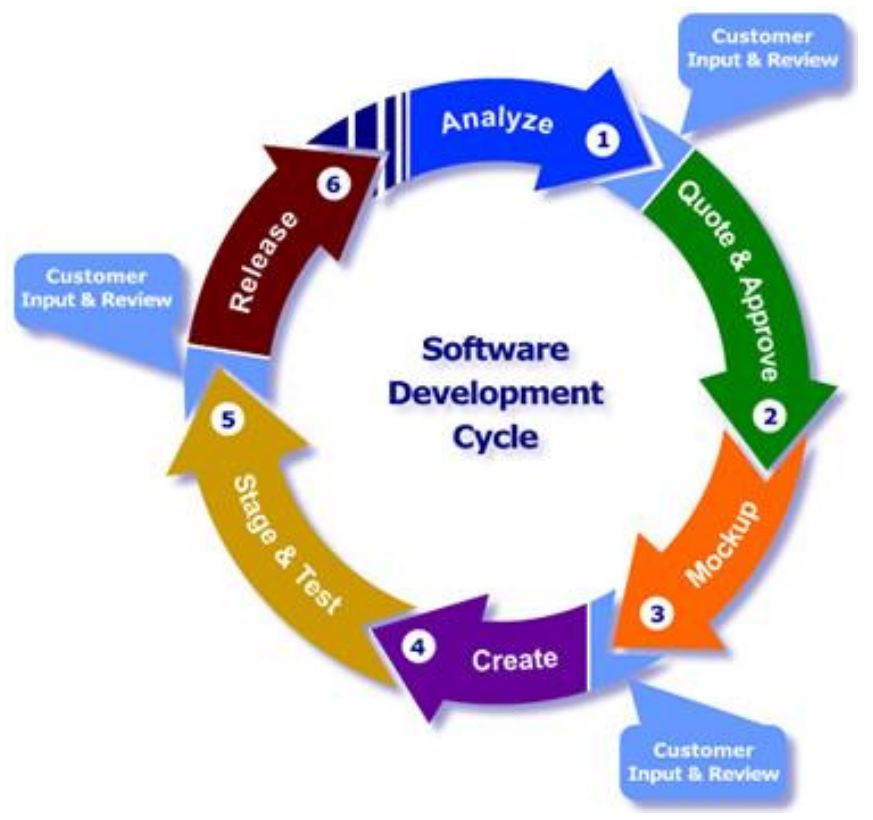

Gambar 1. Metode Fast

Metode FAST memilki beberapa tahapan yang harus dilalui :

1. Defenisi ruang lingkup (Scope Definition), tahapan ini bertujuan untuk mendefenisikan masalah dan tujuan dari pembangunan sistem informasi. 
2. analisi masalah (Problem Analysis), tahapan ini bertujuan untuk mempelajari sistem yang berjalan dan menganalisis temuan-temuan agar dapat menemukan pemahaman yang lebih mendalam akan permasalahan yang ada.

3. Analisis kebutuhan (Requirement Analysis), tahapan ini bertujuan untuk menganalisis kebutuhan apa saja yang dibutuhkan dalam sistem.

4. Desain logis (Logical Desain), tahapan ini bertujuan untuk merancang kebutuhan dan memodelkan sistem.

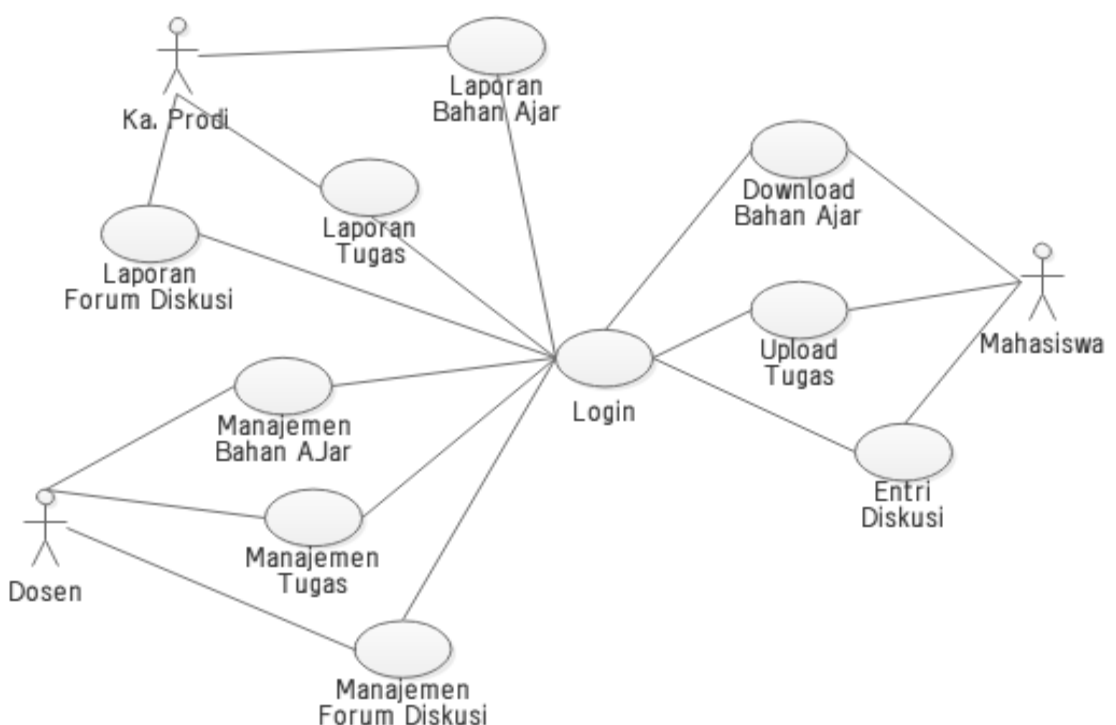

Gambar 2. Use Case Diagram Sistem AT-OTP

Pada gambar 2 dijelaskan bahwa dosen dapat melakukan upload bahan ajar yang kemudian bahan ajar tersebut bisa di download oleh mahasiswa dan ka prodi juga bisa melihat bahan ajar yang di upload oleh dosen. Dosen juga bisa memberikan tugas kepada mahasiswa, dan mahasiswa bisa mengirimkan hasil tugas yang sudah dikerjakan kepada dosen, dan ka prodi juga bisa melihat tugas apa saja yang diberikan oleh dosen dan mahasiswa yang mana yang mengerjakan atau tidak mengerjakan tugas. Dosen dan mahasiswa juga bisa berdiskusi melalui forum diskusi, dan ka prodi bisa melihat keaktifan dosen dan mahasiswa selama proses berdiskusi.

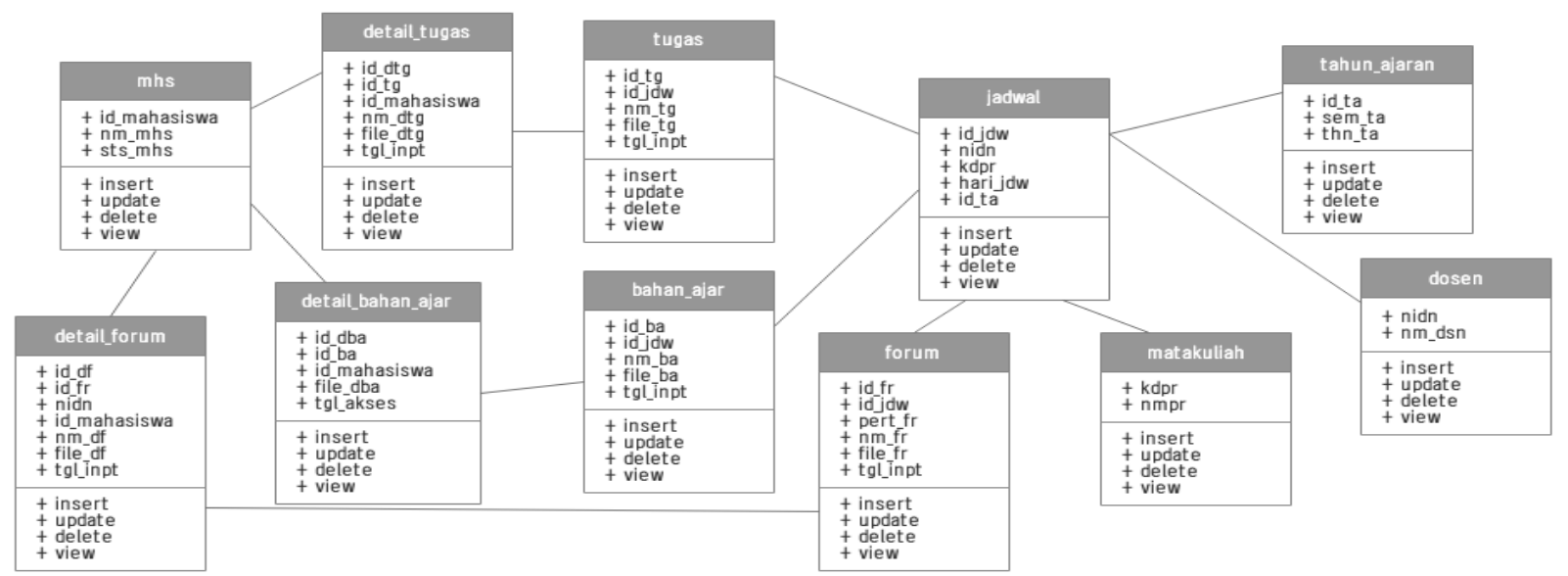

Gambar 3. Class Diagram Sistem AT-OTP 
5. Analisis keputusan (Decision Analysis), tahapan ini bertujuan untuk menentukan perangkat lunak dan perangkat keras apa saja yang diterapkan ke dalam sistem yang dibuat.

6. Desain fisik (Physical Desain), tahapan ini bertujuan untuk melakukan perancangan antarmuka sistem dan database.

7. Kontruksi dan pengujian (Construction and Testing), tahapan ini bertujuan untuk melakukan pengujian terhadap sistem yang dibuat.

\section{HASIL DAN PEMBAHASAN}

Saat ini penggunaan e-learning sudah menjadi suatu kewajiban bagi perguruan tinggi karena proses belajar mengajar yang tidak lagi dilakukan secara tatap muka dengan langsung datang ke kampus, tapi digantikan dengan daring yang membuat mahasiswa dan dosen tidak berada dalam satu ruangan kelas. Melakukan monitoring atau kontrol terhadap perkuliahan secara daring tidak seperti pada perkuliahan tatap muka. Karena pada perkuliahan tatap muka setiap aktifitas perkulihan dapat dimonitoring secara langsung. Seperti pelaksanaan perkuliahannya, pemberian bahan ajar, tugas, serta keaktifan dalam diskusi di kelas.

Perubahan proses belajar mengajar secara tatap muta langsung dengan ke proses daring memiliki cara yang berbeda. Ketika perkuliahan dilakukan secara tatap muka maka bahan ajar yang disampaikan oleh dosen bisa diberikan langsung kepada mahasiswa, dan tentu bahan ajar tersebut bisa langsung dibaca oleh mahasiswa karena dosen dan mahasiswa berada dalam satu ruangan kelas. Tapi ketika perkuliahan secara daring pemberian bahan ajar kepada mahasiswa belum tentu diterima oleh mahasiswa. Berbagai hal bisa saja terjadi ketika mahasiswa mengakses bahan ajar seperti tidak adanya koneksi internet atau memang mahasiswanya yang belum mengakses bahan ajar tersebut.

Tentu hal tersebut harus segara diatasi, dengan adanya sistem AT-OTP, maka dosen dapat mengetahui apakah bahan ajarnya sudah diakses oleh mahasiswa seperti terlihat pada gambar 4.

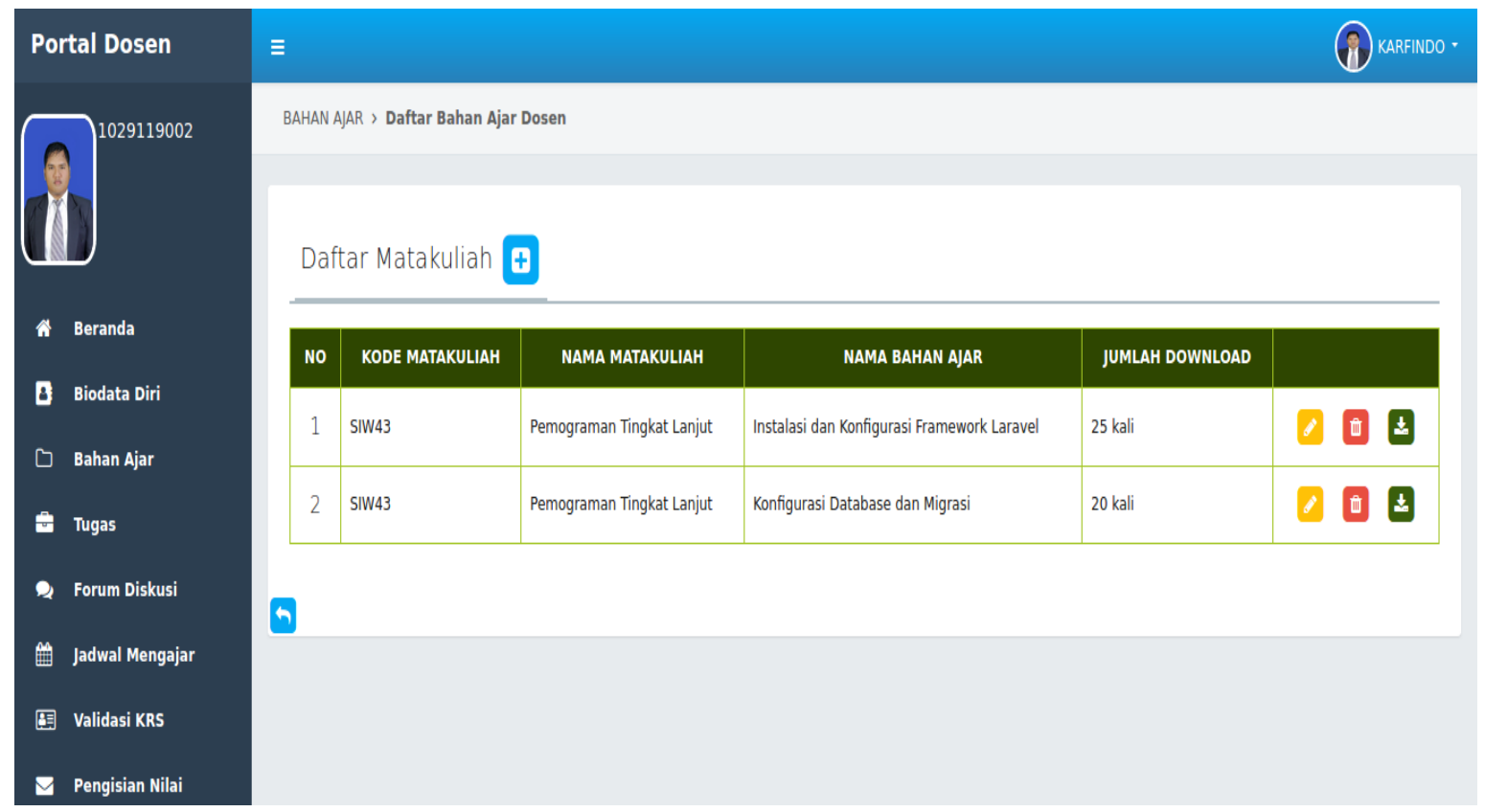

Gambar 4. Daftar Akses Bahan Ajar

Dosen tidak hanya bisa melihat berapa orang mahasiswa yang sudah mengakses bahan ajarrnya tapi juga bisa melihat mahasiswa yang ada di kelasnya apakah ada mengakses bahan ajar pada matakuliah yang lainnya. Kapan diakses oleh mahasiswa tersebut, sehingga dosen bisa mengambil tindakan, jika pada pertemuan yang ke-3 mahasiswa belum mengakses bahan ajarnya dan bahan ajar matakuliah yang lainnya, 
berarti kemungkinan mahasiswa tersebut memiliki kendala mungkin dari segi koneksi internet atau perangkat yang digunakan untuk mengakses bahan ajar.

Dalam pelaksaan perkuliahan biasanya dosen melakukan pengujian tingkat pemahaman mahasiswa dengan memberikan tugas yang mesti dikerjakan oleh mahasiswa. Jika pada perkuliahan tatap muka, tugas yang diberikan pada pertemuan sebelumnya bisa langsung dikumpulkan pada pertemuan berikutnya ketika mahasiswa tersebut hadir pada pertemuan saat pengumpulan tugas. Tapi pada perkuliahan daring, sulit untuk mengetahui penyebab ketika ada mahasiswa yang tidak mengumpulkan tugas. Apakah mahasiswa tersebut tidak mengumpulkan tugas karena foktar koneksi internet atau perangkat yang digunakan bermasalah. Dengan adanya sistem AT-OTP, maka dosen bisa melakukan pengecekan tugas yang diberikan oleh dosen pada matakuliah lainnya kepada mahasiswa yang diampunya, apakah mahasiswa tersebut juga tidak ada mengerjakan tugasnya, seperti yang terlihat pada gambar 5 .

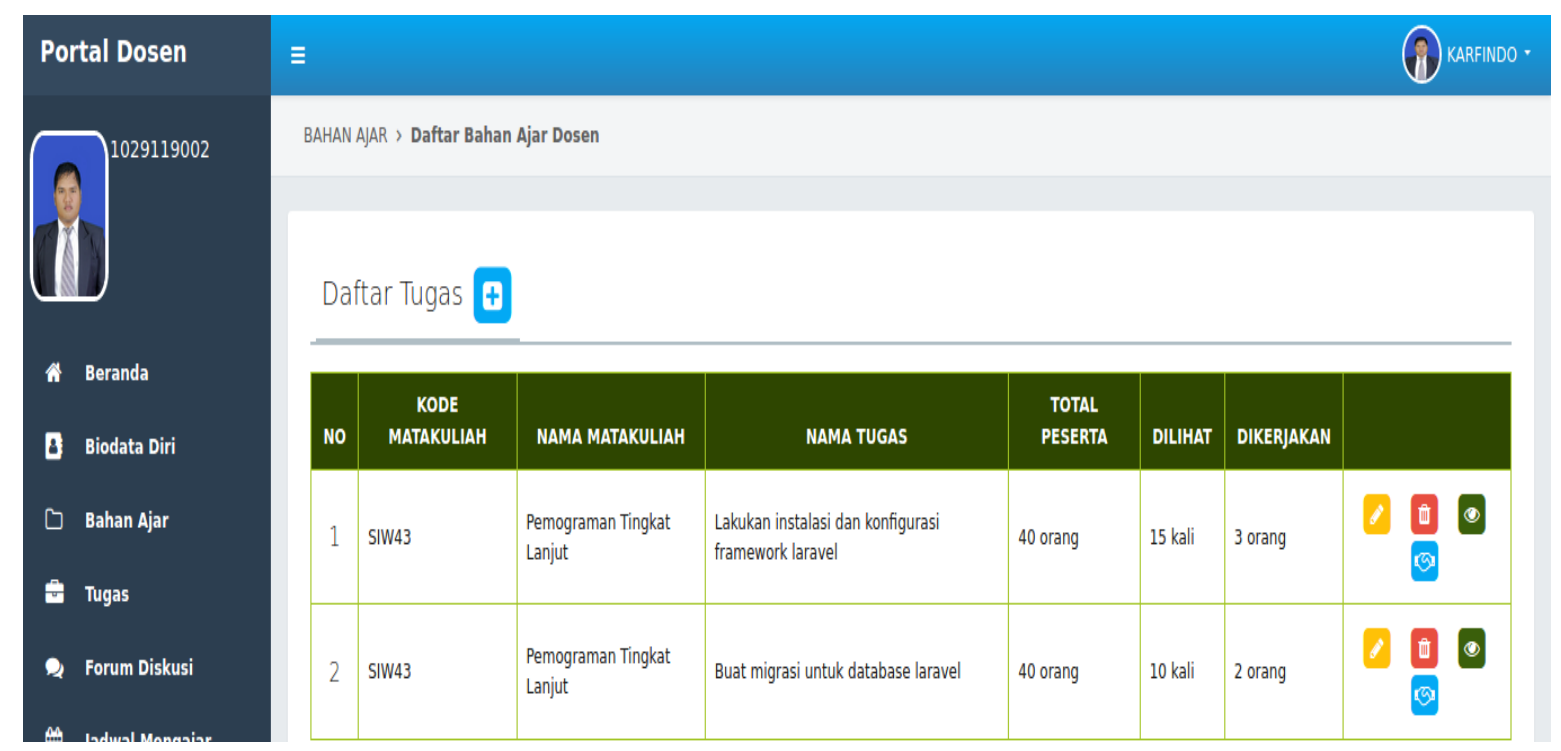

Gambar 5. Daftar Monitoring Tugas

Pada saat perkuliahan tatap muka, maka diskusi terhadap materi bisa langsung dilakukan antara dosen dengan mahasiswa. Jika mahasiswa ada yang kurang dimengerti atau tidak dimengerti terhadap materi yang diberikan maka mahasiswa bisa langsung bertanya kepada dosen. Tapi pada perkuliahan daring tentung forum diskusi merupakan salah satu tempat bagi dosen dan mahasiswa untuk saling berbagi informasi. Tapi terkadang dosen sulit untuk mengetahui siapa saja mahasiswa yang aktif dalam berdiskusi karena dalam satu kelas yang diajar oleh dosen terdapat beberapa mahasiswa, serta topik materi yang didiskusikan juga banyak. Dengan sistem AT-OTP, maka dosen bisa melakukan pengecekan keaktifan mahasiswa dalam berdiskusi pada setiap pertemuan, seperti yang terlihat pada gambar 6 . 


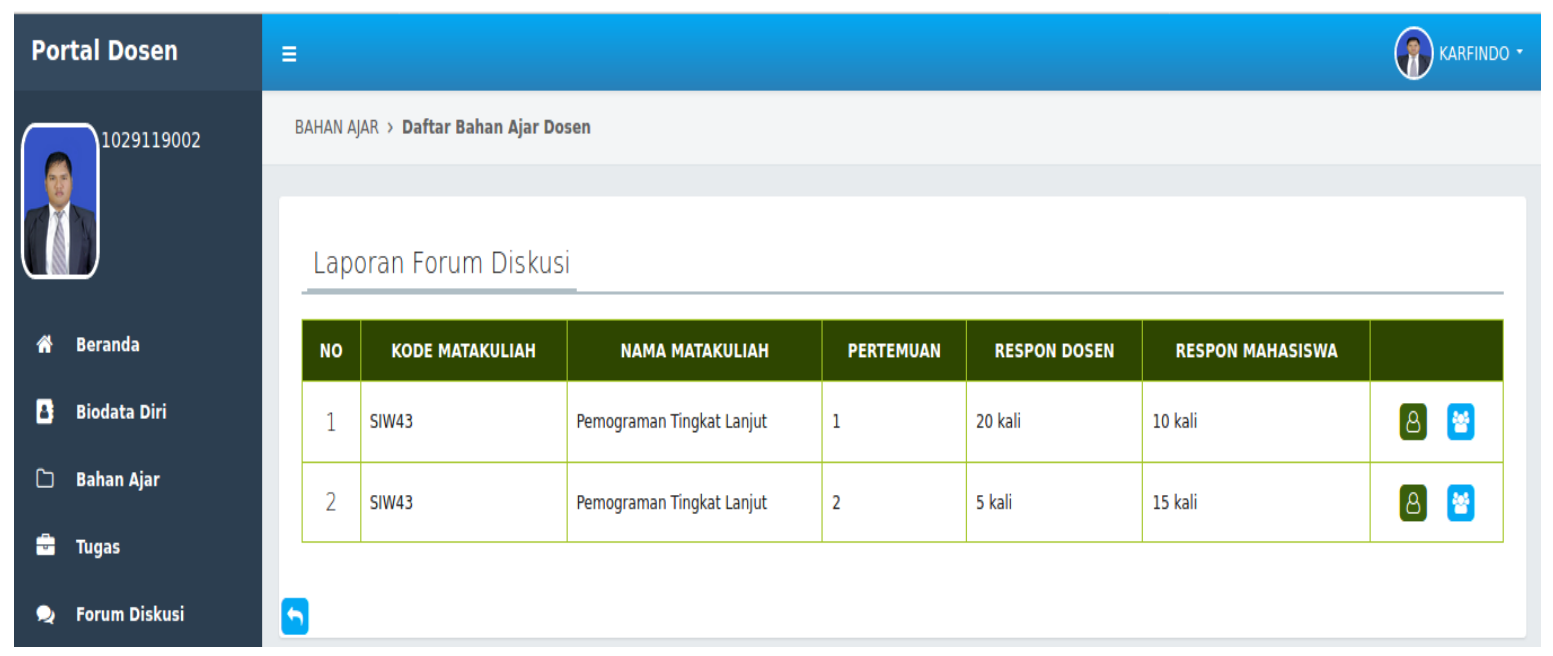

Gambar 6. Daftar Monitoring Forum Diskusi

Dosen bisa mengetahui apakah mahasiswa ada terlibat dalam diskusi pada setiap pertemuan. Ataukah hanya pada beberapa pertemuan saja mahasiswa tidak terlibat. Jika ada mahasiswa yang tidak terlibat dalam diskusi pada salah satu pertemuan, dosen bisa melakukan pengecekan keaktifan mahasiswa tersebut pada matakuliah lainnya yang diambil oleh mahasiswa. Apakah pada pertemuan di minggu yang sama mahasiswa tersebut juga tidak aktif berdiskusi.

Sistem AT-OTP ini merupakan fitur tambahan dalam penggunaan e-learning, dimana dengan sistem ini menggunakan konsep adanya keterbukaan dalam setiap kegiatan perkuliahan. Kegiatan perkuliahan secara umum yang dilakukan adalah adanya pemberian atau sharing bahan ajar, pemberian tugas atau latihan kepada mahasiswa, dan adanya diskusi terhadap bahan ajar yang diberikan. Jika salah satu kegiatan umum ini tidak dilakukan kontrol secara tepat dan cepat maka proses belajar mengajar yang diharapkan tidak akan bisa berhasil. Masalah yang dievaluasi diakhir tentu tidak akan merubah proses yang sebelumnya terjadi, dengan sistem AT-OTP ini evaluasi tidak dilakukan pada akhir perkuliahan saja atau pada saat perkuliahan sudah berakhir, tapi evaluasi dilakukan setiap saat disetiap pertemuan yang dilakukan oleh dosen dan mahasiswa.

Dari sisi penggunaan sistem dilakukan pengujian untuk mengetahui apakah sistem AT-OTP ini mudah untuk digunakan oleh dosen dan mahasiswa maka dilakukanlah pengujian dengan munggunakan system usability scale (SUS) dimana respondennya adalah dosen, mahasiswa dan dosen. SUS dapat digunakan untuk mengukur usability sistem komputer menurut sudut padang subyektif pengguna. SUS berupa kuisioner dengan 10 item pertanyaan. Kuisioner SUS menggunakan 5 poin skala likert yaitu sangat tidak setuju, tidak setuju, netral, setuju, dan sangat setuju.

Tabel 1. Item Pertanyaan SUS

\begin{tabular}{|l|l|}
\hline Kode & Item Pertanyaan \\
\hline R1 & Saya pikir bahwa saya akan lebih sering menggunakan sistem ini \\
\hline R2 & Saya menilai sistem ini terlalu kompleks (memuat banyak hal yang tidak perlu) \\
\hline R3 & Saya menilai sistem ini mudah digunakan \\
\hline R4 & Saya membutuhkan bantuan teknis untuk menggunakan sistem ini \\
\hline R5 & Saya menilai fitur yang disediakan pada sistem ini dirancang dengan baik \\
\hline R6 & Saya menilai terlalu banyak ketidaksesuaian pada sistem ini \\
\hline R7 & Saya merasa kebanyakan orang akan mudah menggunakan sistem ini dengan cepat \\
\hline R8 & Saya menemukan, sistem ini sangat rumit untuk diguanakan \\
\hline R9 & Saya merasa sangat percaya diri menggunakan sistem ini \\
\hline
\end{tabular}


Sampel yang digunakan adalah sebanyak 50 orang mahasiswa, dan 3 orang dosen. Hasil penilaian responden kemudian dihitung dengan menggunakan rumus yang telah ditentukan untuk mendapatkan skor SUS, seperti terlihat pada tabel 2 .

Tabel 2. Hasil Penilaian Responden

\begin{tabular}{|c|c|}
\hline Responden & Skor SUS \\
\hline 1 & 77.5 \\
\hline 2 & 72.5 \\
\hline 3 & 65 \\
\hline Responden & Skor SUS \\
\hline 4 & 80 \\
\hline 5 & 62.5 \\
\hline 6 & 67.5 \\
\hline 7 & 85 \\
\hline 8 & 70 \\
\hline 9 & 75 \\
\hline 10 & 62.5 \\
\hline 11 & 67.5 \\
\hline 12 & 77.5 \\
\hline 13 & 70 \\
\hline 14 & 72.5 \\
\hline 15 & 62.51 \\
\hline 16 & 70 \\
\hline 17 & 75 \\
\hline 18 & 62.5 \\
\hline 19 & 67.5 \\
\hline 20 & 62.5 \\
\hline 21 & 60 \\
\hline 22 & 72.5 \\
\hline 23 & 72.5 \\
\hline 24 & 75 \\
\hline 25 & 67.5 \\
\hline 26 & 65 \\
\hline 27 & 67.5 \\
\hline 28 & 60 \\
\hline 29 & 70 \\
\hline 30 & 72.5 \\
\hline 31 & 75 \\
\hline
\end{tabular}




\begin{tabular}{|c|c|}
\hline 32 & 65 \\
\hline 33 & 65 \\
\hline 34 & 80 \\
\hline 35 & 70 \\
\hline 36 & 72.5 \\
\hline 37 & 70 \\
\hline 38 & 65 \\
\hline Responden & Skor SUS \\
\hline 39 & 67.5 \\
\hline 40 & 70 \\
\hline 41 & 82.5 \\
\hline 42 & 57.5 \\
\hline 43 & 72.5 \\
\hline 44 & 72.5 \\
\hline 45 & 60 \\
\hline 46 & 77.5 \\
\hline 47 & 75 \\
\hline 48 & 80 \\
\hline 49 & 82.5 \\
\hline 50 & 65 \\
\hline 51 & 70 \\
\hline 52 & 65 \\
\hline 53 & 65 \\
\hline Rata-rata Skor SUS & 70.04 \\
\hline
\end{tabular}

Setelah mendapatkan hasil akhir penilaian responden maka selanjutnya adalah menentukan grade hasil penilaian ada 2. Pertama dilihat dari sisi tingkat penerimaan pengguna, grade skala dan adjektif rating yang terdiri tingkat penerimaan pengguna terdapat tiga kategori yaitu not acceptable, marginal dan acceptable. Sedangkan dari sisi tingkat grade skala terdapat enam skala yaitu A, B, C, D, E dan F. dari adjektif rating terdiri dari worst imaginable, poor, ok, good, excellent dan best imaginable seperti yang diperlihatkan pada gambar [7]. 


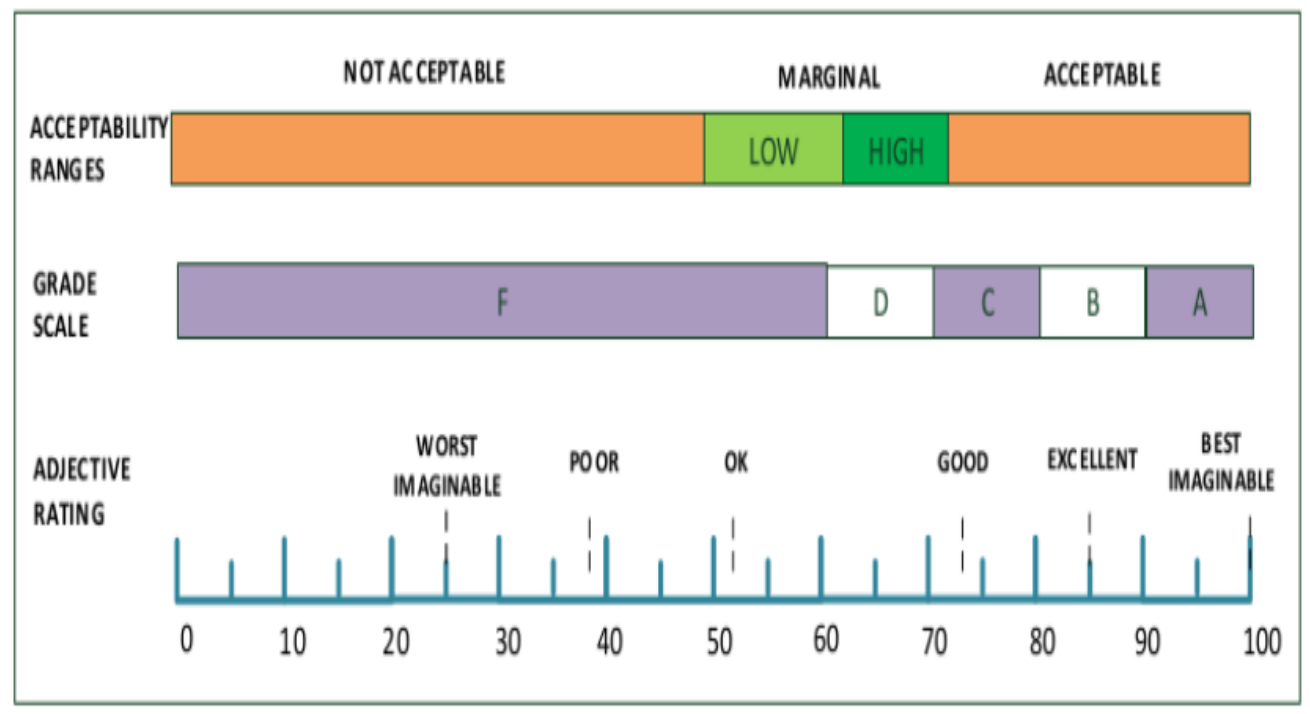

Gambar 7. Penentuan Hasil Penilaian

Penentuan yang kedua dilihat dari sisi percentile range (SUS skor) yang memiliki grade penilaian yang terdiri dari A, B, C, D dan F. dari dua cara penentuan hasil penilaian tersebut maka dapat dilihat hasil penilaian sebagai berikut (Brooke, J, 2013):

1. Acceptability, grade scale, adjective rating dari hasil penilaian yang diberikan responden sebesar 70,04 dengan kententuan penilaian seperti gambar 7. Untuk itu hasil penilaian terhadap sistem AT-OTP sebagai berikut : a) Tingkat penerimaan pengguna masuk dalam kategori acceptable, b) Tingkat grade skala masuk dalam kategori $\mathrm{C}$, c) adjektif rating sistem AT-OTP dapat digunakan dengan mudah oleh mahasiswa dan dosen.

2. SUS skor percentile rank dari hasil penilaian yang diberikan oleh responden sebesar 70,04 berada pada grade $\mathrm{C}$.

Hasil penilaian responden terhadap antarmuka sistem AT-OTP dapat dikatakan baik atau dapat dimanfaatkan oleh pengguna akhir.

\section{KESIMPULAN}

Berdasarkan uraian yang telah disampaikan, dapat diambil kesimpulan bahwa sistem AT-OTP adalah sistem yang digunakan untuk melakukan monitoring terhadap kegiatan proses belajar mengajar secara daring, dengan menggunakan konsep keterbukaan terhadap semua aktifitas yang dilakukan. Sehingga dengan adanya saling terbuka maka masalah yang dihadapi bisa segara diketahui dan dicarikan solusi terhadap permasalah tersebut. Secara umum aktifitas proses belajar mengajar adalah pemberian bahan ajar kepada mahasiswa, memberikan tugas dan latihan untuk dikerjakan oleh mahasiswa, dan diskusi terkait bahan ajar yang diberikan oleh dosen. Semua aktifitas umum itu bias dilakukan monitori dengan menggunakan system AT-OTP.

\section{DAFTAR RUJUKAN}

[1] D. H. Oktawirawan, "Faktor Pemicu Kecemasan Siswa dalam Melakukan Pembelajaran Daring di Masa Pandemi Covid-19,” J. Ilm. Univ. Batanghari Jambi, vol. 20, no. 2, pp. 541-544, 2020.

[2] D. I. K. Subang, "Efektivitas Implementasi Pembelajaran Daring (FULL Online) Dimasa Pandemi COVID-19 pada Jenjang Sekolah Dasar Di Kabupaten Subang," J. Ilm. PGSD STKIP Subang, vol. VI, no. 01 , pp. 1-9, 2020 .

[3] R. Pakpahan and Y. Fitriani, "p-ISSN : 2598-8700 ( Printed ) ANALISA PEMANFAATAN TEKNOLOGI INFORMASI DALAM PEMBELAJARAN JARAK JAUH DI TENGAH PANDEMI 
VIRUS CORONA COVID-19 JISAMAR ( Journal of Information System , Applied , Management , Accounting and Researh ) p-ISSN : 2598-8700 ( Pri,” J. Inf. Syst. Applied, Manag. Account. Res., vol. 4, no. 2, pp. 30-36, 2020.

[4] S. Mariko, "PERANCANGAN PORTAL E-LEARNING MENGGUNAKAN DRUPAL CMS SEBAGAI PENUNJANG PERKULIAHAN PADA MASA PANDEMI COVID-19,” Ilm. Educ., vol. 6, no. 2, 2020.

[5] Y. Pujilestari, "Dampak Positif Pembelajaran Online Dalam Sistem Pendidikan Indonesia Pasca Pandemi Covid-19," Adalah Bul. Huk. dan Keadilan, vol. 4, no. 1, pp. 49-56, 2020.

[6] Y. P. Utami, D. Alan, D. Cahyono, and U. T. Indonesia, "STUDY AT HOME: ANALISIS KESULITAN BELAJAR,” J. Ilm. Mat. Realis., vol. 1, no. 1, pp. 20-26, 2020.

[7] A. Sadikin et al., "Pembelajaran Daring di Tengah Wabah Covid-19 ( Online Learning in the Middle of the Covid-19 Pandemic )," J. Ilm. Pendidik. Biol., vol. 6, no. 1, pp. 214-224, 2020.

[8] B. Setiaji, P. Ariadi, and C. Dinata, "Analisis kesiapan mahasiswa jurusan pendidikan fisika menggunakan e-learning dalam situasi pandemi Covid-19 Analysis of e-learning readiness on physics education students during Covid-19 pandemic,” J. Inov. Pendidik. IPA, vol. 6, no. 1, pp. 59-70, 2020.

[9] F. S. Didin, I. Mardiono, and H. D. Yanuarso, "Analisis Beban Kerja Mental Mahasiswa saat Perkuliahan Online Synchronous dan Asynchronous Menggunakan Metode Rating Scale Mental Effort," J. OPSI, vol. 13, no. 1, pp. 49-55, 2020.

[10] Brooke, J. (2013). SUS: A Retrospective. Journal of Usability Studies, 29-40. 